\title{
Effects of COVID-19 on testicular function
}

Nasser Mikhail MD*, Vahid Mahabadi MD

Endocrinology Division, Department of Medicine, Olive-View UCLA Medical Center, David Geffen-UCLA School of Medicine, Sylmar, CA, USA. *Corresponding Author: Nasser Mikhail, Endocrinology Division, Department of Medicine, Olive-View UCLA Medical Center, David Geffen-UCLA School of Medicine, Sylmar, CA, USA

Received date: February 25, 2021 ; Accepted date: March 15, 2021; Published date: March 17,2021

Citation: N Mikhail, V Mahabadi. (2021) Effects of COVID-19 on testicular function J. Endo and Dis; 5(1); DOI:10.31579/2640-1045/104

Copyright: (C) 2021 Nasser Mikhail, This is an open access article distributed under the Creative Commons Attribution License, which permits unrestricted use, distribution, and reproduction in any medium, provided the original work is properly cited.

\section{Abstract}

Background: The impact of coronavirus disease 2019 (COVID-19) caused by severe acute respiratory syndromecoronavirus 2 (SARS-Cov-2) on testicular function is unclear.

Objective: To clarify the effects of COVID-19 on male gonadal function.

Methods: Pubmed search up to February 24, 2021. Search terms included COVID-19, testicles, testosterone, spermatogenesis, hypogonadism. Case reports, retrospective, prospective and autopsy studies are included.

Results: Prevalence of patients hospitalized with COVID-19 having scrotal pain varies from 0-19\%. Orchitis and/or epididymitis were demonstrated by scrotal ultrasound (US) in approximately $22-42 \%$ of men with COVID-19 admitted to the hospital and can be frequently asymptomatic. Circulating testosterone levels are reduced in men admitted with COVID-19 with concomitant elevation of luteinizing hormone (LH) suggesting testicular dysfunction. Men affected with COVID-19 exhibit abnormal semen parameters. Most, but not all, studies failed to detect SARS-CoV-2 in semen. Autopsy studies showed extensive damage of testicular tissues of men who died from severe COVID-19.

Conclusion: COVID-19 negatively affects almost all aspects of male gonadal function. Physicians should evaluate testicular function during and after recovery from COVID-19 to preserve normal fertility.

Key words: COVID-19; fertility; male; semen; spermatogenesis; testosterone; orchitis; testes

\section{Introduction}

Many viruses such as mumps, human immunodeficiency virus (HIV), Zika virus, and others can invade the testicles [1] SARS-Cov-2 uses angiotensin converting enzyme 2 (ACE2) as receptor and the transmembrane protease serine 2 (TMPRSS2) as co-receptor for host cell binding and penetration [2]. Conflicting data exist regarding expression of these receptors in testicular tissues. Thus, some workers found that ACE2 receptors were expressed in testicular germ cells, Leydig cells, and Sertoli cells [3, 4]. In addition, ACE2 receptors and TMPR22 are expressed in prostate [5]. However, Pan et al [6] found that ACE2 and TMPRSS2 are expressed sparsely in the human testes, whereas Stanley et al [7] failed to detect co-expression of ACE2 and TMPRSS2 in testicular cells. Nevertheless, emerging data provide convincing evidence that several men affected with COVID-19 exhibit significant gonadal dysfunction. The latter is reflected by frequent presence of scrotal symptoms in COVID-19 patients, and evidence of orchitis and epididymitis by scrotal imaging. In addition, there is impairment of semen parameters in patients examined at various stages of COVD-19. Moreover, autopsy studies demonstrated extensive testicular damage in patients who died from severe COVID-19.

\section{Testicular symptoms in patients with COVID-19}

Kim et al [8] described a 42-year-old male who presented with testicular pain for 8 days and was found few days later to have COVID-19 pneumonia. Testicular exam revealed "no abnormal findings" [8]. La Marca et al [9] reported a 43-year-old man who had COVID-19 pneumonia associated with scrotal pain. Scrotal US was consistent with epididymitis [9]. In a cross-sectional study, Pan et al [6] reported that 6 out $34(19 \%)$ men had scrotal discomfort around the time of COVID-19 confirmation. In a prospective study from Turkey of 91 men hospitalized with COVID-19, Ediz et al [10] reported that $11 \%$ of men had testicular pain. The latter was not associated with age nor with several inflammatory markers of COVID-19 [10]. On the other hand, in a retrospective study of 253 men, $81 \%$ of them had mild COVID-19, the authors did not identify any patients with scrotal complains [11].

\section{Testicular imaging in patients with COVID-19}

The first case of testicular inflammation associated with COVID-19 was reported in the pediatric population by Gagliardi et al [12] who reported a 14-year-old boy presenting with scrotal swelling and fever. Scrotal US showed orchitis and epididymitis [12]. Bridwell et al [13] described a 37year-old man with mild asymptomatic COVID-19 pneumonia presenting with bilateral testicular pain, mild fever, and myalgia approximately 10 days after testing positive with nasopharyngeal polymerase chain reaction (NP-PCR) for COVID-19. Orchitis was confirmed by US without evidence of epididymitis [13].

In a retrospective study from Wuhan, China, Chen et al [14] performed testicular US in 142 hospitalized patients with confirmed COVID-19 and 
median age 58.3 years (range 24-93). They found that 32 of $142(22.5 \%)$ of patients had evidence of acute orchitis $(n=10)$, epididymitis $(n=7)$, or epididymo-orchitis $(n=15)$ [14]. The risk of scrotal infection increased with age and severity of COVID-19. Thus, prevalence reached $53 \%$ in men older than 80 years, and acute scrotal infection was more likely to occur in the group with severe COVID-19 compared to the group with non-severe disease, $35.6 \%$ and $13.5 \%$, respectively $(\mathrm{P}=0.002)$ [14]. Interestingly, only 10 of the $32(31.3 \%)$ patients with abnormal scrotal US exhibited acute scrotal symptoms. Conversely, 3 of the 110 patients (2.7\%) who had negative scrotal US had acute scrotal symptoms [14]. These observations suggest that orchitis associated with COVID-19 may be asymptomatic. The latter notion might be also true with respect to epididymitis. In fact, in a small retrospective study from Brazil, Carneiro et al [15] performed testicular US in 26 young men (age range 21-42 years) hospitalized for mild to moderate COVID-19. None of patients had scrotal symptoms [15]. Using similar diagnostic criteria to study of Chen et al [15], they found that 11 patients (42.3\%) had US signs of epididymitis, and no patient had signs of orchitis [15]. These findings may have important clinical applications given the important role of the epididymis in male fertility, and certainly require confirmation in larger studies including broader patient population.

\section{Testosterone levels in patients with COVID-19}

Testosterone is produced in testicles by Leydig cells and is essential in maintaining normal spermatogenesis and male fertility [16]. There is general agreement that circulating testosterone levels may be reduced in patients with COVID-19 admitted to the hospital [17-19]. Cayan et al [17] have shown that total testosterone levels significantly decreased in a subgroup of 24 Turkish men from $458 \pm 198 \mathrm{ng} / \mathrm{dl}$ prior to COVID-19 infection to $315 \pm 120 \mathrm{ng} / \mathrm{dl}$ on the first day of hospital admission $(\mathrm{P}=0.003)$. Furthermore, available data suggest that the degree of hypogonadism increases in parallel to the severity of COVID-19. Thus, in one prospective study from Turkey of young patients (mean age \pm standard deviation $35.5 \pm 9.8$ years), Okcelik [18] showed that patients with COVID-19 pneumonia had significantly lower testosterone levels than COVID-19 patients without pneumonia, 260.3 and $435.1 \mathrm{ng} / \mathrm{dl}$, respectively $(\mathrm{P}=0.01)$. In one Chinese retrospective study, Ma et al [19] compared serum levels of testosterone in 119 young men (age range 2049 years) hospitalized for COVID-19 (84\% of them had moderate disease) with 273 age-matched control subjects. They found a non-significant trend of testosterone levels to be lower in COVID-19 patients compared with control subjects, median [interquartile range, (IQR)] being 397 (314574) and 464 (351-638) ng/dl, respectively ( $\mathrm{P}=0.18)$ [19]. Meanwhile, luteinizing hormone (LH) values were significantly higher in patients compared with control individuals; median (IQR) 6.36 (4.63-8.38) and 3.38 (2.48-4.52) $\mathrm{mIU} / \mathrm{L}$, respectively, $\mathrm{P}<0.0001)$ [19]. It follows that the testosterone/LH ratio, a marker of testicular function, was significantly lower in patients with COVID-19 compared with healthy subjects [19]. Limited data suggest that sex hormone abnormalities associated with COVID-19 may normalize after recovery. Thus, Xu et al [20] showed that serum testosterone and gonadotropin levels were within normal range in 39 men after recovery from COVID-19. Taken together, the above studies suggest that men hospitalized with COVID-19 may have testicular dysfunction as reflected by low serum testosterone and elevated LH concentrations. However, it is unclear whether the decreased testosterone levels are directly caused by COVID-19 or simply a marker of severe illness or both.

\begin{tabular}{|c|c|c|c|c|}
\hline & Ma et al [27] & Li et al [28] & Achua et al [29] & Yang et al [30] \\
\hline $\begin{array}{l}\text { Characteristics of } \\
\text { deceased subjects }\end{array}$ & $\begin{array}{l}5 \text { deceased patients } \\
\text { with COVID-19 (age } \\
\text { range } 51-83 \text { years), } \\
\text { and } 3 \text { control } \\
\text { deceased subjects }\end{array}$ & $\begin{array}{c}6 \text { deceased patients } \\
\text { with COVID-19, and } \\
6 \text { control (age range } \\
51-83 \text { years) } \\
\text { deceased subjects }\end{array}$ & $\begin{array}{l}6 \text { deceased patients } \\
\text { with COVID-19 } \\
\text { (age range } 20-87 \\
\text { years), and } 3 \text { control } \\
\text { subjects (age range }\end{array}$ & $\begin{array}{l}11 \text { deceased patients with } \\
\text { COVID-19 (age range } 42-87 \\
\text { years), and } 5 \text { control } \\
\text { deceased subjects (age range }\end{array}$ \\
\hline
\end{tabular}

Impairment of spermatogenesis in men with COVID19

In an Italian prospective study, Gacci et al [21] examined semen parameters in 43 patients who recovered from COVID-19 after 2 consecutive negative nasopharyngeal swabs for SARS-CoV-2 RNA (median time from the first positive to second consecutive negative test was 31 days, range 3-65 days). They found that 8 patients $(18.6 \%)$ had azoospermia, and $3(7.0 \%)$ patients had oligospermia $(<2$ million sperms $/ \mathrm{ml}$ ). Interestingly, semen impairment was significantly related to COVID-19 severity [21]. Thus, azoospermia was present in 4 of 5 patients admitted to the intensive care unit, in 3 of 26 patients hospitalized on Medicine wards, and in only one patient among the 12 non-hospitalized patients $(\mathrm{P}<0.001)$ [21]. All patients with azoospermia had normal fertility history and had biological children [21]. In another prospective study from Germany, Holtmann et al [22] showed that patients $(n=2)$ with moderate COVID-19 had significant impairment of sperm quality including sperm concentration, total number of sperms of ejaculate, and motility compared with patients who recovered from mild COVID-19 $(n=18)$ and control men $(n=14)$. Although medications (e.g. corticosteroids), fever, and previous severe illness may play a role in sperm abnormalities [23, 24], these results suggest that SARS-CoV-2 could be a factor implicated in defective spermatogenesis. Unfortunately, repeat semen analysis at regular intervals after recovery was not performed to assess the course and pattern of sperm impairment [21, 22].

\section{Presence of SARS-CoV-2 in the semen}

Available data suggest that detection of SARS-CoV-2 in semen is rare. $\mathrm{Li}$ et al [25] detected SAR-CoV-2 virus RNA in the semen of 4 out of 15 acutely ill and 2 out of 23 men recovering from COVID-19. Among 43 men who recovered from COVID-19, Gacci et al [21] detected SARSCoV-2 in semen of only one patient in whom semen sample was collected 21 days after the second negative nasopharyngeal swab. Importantly, his partner did not test positive for SARS-CoV-2 [21]. Meanwhile, 14 studies $(n=299)$, including 2 studies that described men with orchitis-like symptoms, failed to demonstrate SARS-CoV-2 in seminal fluid among patients affected with various stages of COVID-19 [26].

\section{Autopsy studies}

Postmortem examination of testicles of patients who died from COVID19 can shed light on direct impact of severe COVID-19 on gonadal function. Results of the autopsy studies, summarized in table 1, are variable due to differences in patients' characteristics, timing of death after COVID-19 infection and methodological issues. Most autopsy studies showed severe injury of seminiferous tubules, germ cells, Leydig cells, and variable degrees of apoptosis and interstitial cellular infiltration of inflammatory cells. Two studies showed that Sertoli cells were spared $[27,29]$. On the contrary Yang et al [30] described severe injury of Sertoli cells. Interestingly, while viral particles were not identified in most studies, Ma et al [27] have detected viral particles in all testicular autopsies examined $(n=5)$. In a proteomic (i.e protein quantification) autopsy study including samples from 5 patients who died from COVID19 pneumonia, Nie et al [31] found reduced Leydig cells and sperm motility factor. In addition, there was evidence of reduced testicular biosynthesis of cholesterol, the source of testosterone [31]. 


\begin{tabular}{|c|c|c|c|c|}
\hline & $\begin{array}{l}\text { without COVID-19 } \\
\text { (age range 71-80 } \\
\text { years) }\end{array}$ & $\begin{array}{l}\text { without COVID-19 } \\
\text { (age range 56-85 } \\
\text { years) }\end{array}$ & $\begin{array}{l}\text { 28-77 years who } \\
\text { died from non- } \\
\text { COVID-19 causes } \\
\end{array}$ & $\begin{array}{l}\text { 49-75 years) were used for } \\
\text { studies of Leydig cells }\end{array}$ \\
\hline Histopathology & $\begin{array}{l}\text { Degenerated germ } \\
\text { cells in COVID-19 } \\
\text { autopsies, Sertoli } \\
\text { cells were spared and } \\
\text { similar to control } \\
\text { testicles }\end{array}$ & $\begin{array}{c}\text { Thinning of } \\
\text { seminiferous } \\
\text { epithelium, shedding } \\
\text { of spermatogonia, } \\
\text { interstitial edema in } \\
\text { testicles and } \\
\text { epididymis of } \\
\text { COVID-19 autopsies }\end{array}$ & $\begin{array}{c}3 \text { of } 6 \text { COVID-19 } \\
\text { testes had } \\
\text { degenerated germ } \\
\text { cells, with sparing } \\
\text { of Sertoli cells, and } \\
\text { early maturation } \\
\text { arrest. }\end{array}$ & $\begin{array}{c}9 \text { of } 11 \text { testicles showed } \\
\text { various degrees of } \\
\text { seminiferous tubules injury. } \\
\text { Sertoli cells showed } \\
\text { swelling, vacuolation, } \\
\text { cytoplasmic rarefaction, and } \\
\text { detachment from basement } \\
\text { membrane. Mean number of } \\
\text { Leydig cells was } 2.2 \text { vs } 7.8 \\
\text { in COVID-19 and control } \\
\text { testicles (P<0.001). } \\
\text { Spermatogenesis was } \\
\text { normal for age. }\end{array}$ \\
\hline $\begin{array}{c}\text { Apoptosis in COVID- } \\
19 \text { testes }\end{array}$ & $\begin{array}{l}\text { Number of apoptotic } \\
\text { cells greater than } \\
\text { control testicles. }\end{array}$ & $\begin{array}{c}\text { Proportion of } \\
\text { apoptotic cells in } \\
\text { COVID-19 testicles } \\
\text { was } 2.95 \text { fold higher } \\
\text { than in control testes } \\
(95 \% \mathrm{CI}, 1.26-6.90, \\
\mathrm{P}=0.018)\end{array}$ & Not reported & Not reported \\
\hline $\begin{array}{l}\text { Immune cells in } \\
\text { COVID-19 testes }\end{array}$ & $\begin{array}{c}\text { Scattered infiltration } \\
\text { of CD3 }{ }^{+} \mathrm{T} \\
\text { lymphocytes, CD20 } \\
\text { B lymphocytes, } \\
\text { CD68+ } \\
\text { macrophages, } \\
\text { activated B cells and } \\
\text { plasma cells. Such } \\
\text { cell infiltration is } \\
\text { rare in control } \\
\text { testicles. }\end{array}$ & $\begin{array}{c}\text { Infiltration of CD3 }{ }^{+} \mathrm{T} \\
\text { lymphocytes, CD68+ } \\
\text { macrophages in all } \\
\text { COVID-19 testicles. } \\
\text { Precipitation of IgG } \\
\text { in } 4 \text { of } 6 \text { COVID-19 } \\
\text { patients' } \\
\text { seminiferous tubules, } \\
\text { and no such } \\
\text { precipitation in } \\
\text { control testicles }\end{array}$ & $\begin{array}{c}\text { One of } 6 \text { COVID-19 } \\
\text { testes showed } \\
\text { lymphocyte and } \\
\text { macrophage } \\
\text { infiltration }\end{array}$ & $\begin{array}{c}\text { Infiltration of } \mathrm{CD}^{+} \mathrm{T} \\
\text { lymphocytes, CD68+ } \\
\text { macrophages }\end{array}$ \\
\hline $\begin{array}{c}\text { Detection of nucleic } \\
\text { acid of SARS-CoV-2 } \\
\text { by reverse } \\
\text { transcription- } \\
\text { polymerase chain } \\
\text { reaction }\end{array}$ & $\begin{array}{c}2 \text { of } 5 \text { COVID-19 } \\
\text { testicles were } \\
\text { positive }\end{array}$ & Not reported & Not reported & $\begin{array}{l}\text { One COVID-19 testicle was } \\
\text { positive }\end{array}$ \\
\hline $\begin{array}{c}\text { Immunohistochemistry } \\
\text { studies }\end{array}$ & $\begin{array}{l}\text { Testicular COVID- } \\
19 \text { sections stained } \\
\text { positive for the spike } \\
\text { protein of SARS- } \\
\text { Cov-2 }\end{array}$ & $\begin{array}{l}\text { ACE2 protein was } \\
\text { highly expressed in } \\
\text { Leydig cells in both } \\
\text { COVID-19 and } \\
\text { control autopsies }\end{array}$ & $\begin{array}{c}\text { ACE2 protein } \\
\text { expression was } \\
\text { significantly } \\
\text { increased in the } 3 \\
\text { COVID-19 testicles } \\
\text { with abnormal } \\
\text { spermatogenesis } \\
\text { compared with the } 3 \\
\text { COVID-19 testicles } \\
\text { with normal } \\
\text { spermatogenesis } \\
\end{array}$ & $\begin{array}{c}\text { ACE2 protein was highly } \\
\text { expressed in Leydig cells, } \\
\text { and diffusely in Sertoli cells, } \\
\text { not in spermatogonia }\end{array}$ \\
\hline $\begin{array}{c}\text { Demonstration of viral } \\
\text { particles by electron } \\
\text { microscopy }\end{array}$ & $\begin{array}{c}\text { Coronavirus-like } \\
\text { particles in } \\
\text { interstitial } \\
\text { compartment in the } 5 \\
\text { COVID-19 testicles. }\end{array}$ & Not performed & $\begin{array}{c}\text { Coronavirus-like } \\
\text { particles in } 1 \text { of } 6 \\
\text { autopsies of patients } \\
\text { with COVID-19 }\end{array}$ & $\begin{array}{c}\text { Viral particles not identified } \\
\text { in } 3 \text { testicular autopsies } \\
\text { examined. }\end{array}$ \\
\hline Comments & & & $\begin{array}{l}\text { Viral particle was } \\
\text { also demonstrated in } \\
\text { testicles of one } \\
\text { patient who } \\
\text { recovered from } \\
\text { COVID-19 }\end{array}$ & $\begin{array}{l}\text { Fever and use of } \\
\text { glucocorticoid were } \\
\text { reported in } 10 \text { patients. }\end{array}$ \\
\hline
\end{tabular}




\section{Clinical implications}

The above results have 2 major implications. First, since orchitis and/or epididymitis, both symptomatic and asymptomatic, are not uncommon among patients hospitalized with COVID-19, it is essential for physicians to elicit history regarding any scrotal complaints [14]. In case of any suspicion of scrotal infection, we recommend performing a scrotal US for further evaluation. If the frequent occurrence of asymptomatic cases of orchitis and/or epididymitis is replicated in future studies, scrotal US should be considered in all men hospitalized for COVID-19. Second, the demonstration of hypogonadism and impairment of spermatogenesis in men hospitalized with COVID-19 implies that measurement of serum testosterone and semen analysis should be repeated after recovery to rule out any persistent abnormalities that may compromise fertility. This evaluation is particularly important in patients in reproductive age who wish to have biological children.

\section{Conclusions and current needs}

Increasing evidence suggest that the testicles may be among the main targets of SARS-CoV-2. COVID-19 may be associated with multiple abnormalities relevant to male gonadal function. These include the common occurrence of scrotal pain, evidence of orchitis and epididymitis, sex-hormone defects consistent with testicular failure (i.e. hypergonadotropic hypogonadism), and impairment of spermatogenesis. Furthermore, autopsy studies showing degeneration of germ cells, and inflammatory cell infiltration represent direct evidence of testicular involvement in patients who died from severe COVID-19. Meanwhile, the available studies suffer from several limitations such as inclusion of small number of subjects and unavailability of patients' medical tests prior to COVID-19 infection for comparison (e.g. testosterone levels and semen analysis). In addition, none of the available studies performed regular follow-up of abnormal investigations from the time of start of acute COVID-19 infection until recovery and thereafter. The demonstration of SARS-CoV-2 in few semen specimens of COVID-19 patients, although uncommon, is somewhat disturbing. Nevertheless, it is unknown whether SARS-CoV-2 viral particles detected in semen are still infective, and if so, at what stage of the disease. While there is no current evidence that COVID-19 is sexually transmitted, caution should be exercised when managing the semen of patients recovering from COVID19 for purposes of assisted reproduction and cryopreservation until definitive evidence is established.

\section{Conflict of interest}

The authors do not have conflicts of interest to declare.

\section{Abbreviations}

COVID-19: coronavirus disease 2019

SARS-CoV-2: severe acute respiratory syndrome coronavirus 2

ACE2; angiotensin-converting enzyme

\section{References}

1. Liu W, Han R, Wu H, Han D. (2018) Viral threat to male fertility. Andrologia. 50(11):e13140.

2. Hoffmann M, Kleine-Weber H, Schroeder S, et al. (2020) SARSCoV-2 Cell Entry Depends on ACE2 and TMPRSS2 and Is Blocked by a Clinically Proven Protease Inhibitor. Cell. 181(2):271-280.e8.

3. Wang Z, Xu X. (2020) scRNA-seq profiling of Human Testes Reveals the Presence of the ACE2 Receptor, A Target for SARSCoV-2 Infection in Spermatogonia, Leydig and Sertoli Cells. Cells. 9(4):920.

4. Shen Q, Xiao X, Aierken A, Yue W, Wu X, et al. (2020) The ACE2 expression in Sertoli cells and germ cells may cause male reproductive disorder after SARS-CoV-2 infection. J Cell Mol Med. 24(16):9472-9477.

5. Song H, Seddighzadeh B, Cooperberg MR, Huang FW. (2020) Expression of ACE2, the SARS-CoV-2 Receptor, and TMPRSS2 in Prostate Epithelial Cells. Eur Urol.78 (2):296-298.

6. Pan F, Xiao X, Guo J, Song Y, Li H, Patel DP, et al. (2020) No evidence of severe acute respiratory syndrome-coronavirus 2 in semen of males recovering from coronavirus disease 2019. Fertil Steril. 113(6):1135-1139.

7. Stanley KE, Thomas E, Leaver M, Wells D. (2020) Coronavirus disease-19 and fertility: viral host entry protein expression in male and female reproductive tissues. Fertil Steril. 114(1):33-43.

8. Kim J, Thomsen T, Sell N, Goldsmith AJ. (2020) Abdominal and testicular pain: An atypical presentation of COVID-19. Am J Emerg Med. 38(7):1542.e1-1542.e3.

9. La Marca A, Busani S, Donno V, Guaraldi G, Ligabue G, Girardis M. (2020) Testicular pain as an unusual presentation of COVID19: a brief review of SARS-CoV-2 and the testis. Reprod Biomed Online. 41(5):903-906.

10. Ediz C, Tavukcu HH, Akan S, Kizilkan YE, Alcin A, et al. (2020) Is there any association of COVID-19 with testicular pain and epididymo-orchitis? Int J Clin Pract. e13753.

11. Alkhatatbeh H, Alzaghari D, Alkhashman A, Azab M, Edwan GMA, Abufaraj M. (2020) Does severe acute respiratory syndrome coronavirus-2 (SARS-CoV-2) cause orchitis in patients with coronavirus disease 2019 (COVID-19)? Arab J Urol. 18(3):129-133.

12. Gagliardi L, Bertacca C, Centenari C, Merusi I, Parolo E, et al. (2020) Orchiepididymitis in a boy with COVID-19. Pediatr Infect Dis J. 39(8):e200-e202.

13. Bridwell RE, Merrill DR, Griffith SA, Wray J, Oliver JJ. (2020) A coronavirus disease 2019 (COVID-19) patient with bilateral orchitis: A case report. Am J Emerg Med.S0735-6757(20)307610 .

14. Chen L, Huang X, Yi Z, Deng Q, Jiang N, Feng C, Zhou Q, Sun B, Chen W, Guo R.( 2020) Ultrasound Imaging Findings of Acute Testicular Infection in Patients With Coronavirus Disease 2019: A Single-Center-Based Study in Wuhan, China. J Ultrasound Med.

15. Carneiro F, Teixeira TA, Bernardes FS, Pereira MS, Milani G, Duarte-Neto AN, Kallas EG, Saldiva PHN, Chammas MC, Hallak J. (2021) Radiological patterns of incidental epididymitis in mildto-moderate COVID-19 patients revealed by colour Doppler ultrasound. Andrologia. e13973.

16. Smith LB, Walker WH. (2014) The regulation of spermatogenesis by androgens. Semin Cell Dev Biol. 30:2-13.

17. Çayan S, Uğuz M, Saylam B, Akbay E. (2020) Effect of serum total testosterone and its relationship with other laboratory parameters on the prognosis of coronavirus disease 2019 (COVID-19) in SARS-CoV-2 infected male patients: a cohort study. Aging Male. 3:1-11.

18. Okçelik S. (2021) COVID-19 pneumonia causes lower testosterone levels. Andrologia. 53(1):e13909.

19. Ma L, Xie W, Li D, Shi L, Ye G, et al. (2020) Evaluation of sexrelated hormones and semen characteristics in reproductive-aged male COVID-19 patients. J Med Virol. 10.1002/jmv.26259.

20. Xu H, Wang Z, Feng C, Yu W, Chen Y, Zeng X, Liu C. (2021) Effects of SARS-CoV-2 infection on male sex-related hormones in recovering patients. Andrology. 9(1):107-114.

21. Gacci M, Coppi M, Baldi E, et al. (2021) Semen impairment and occurrence of SARS-CoV-2 virus in semen after recovery from COVID-19. Hum Reprod. Epub ahead of print 
22. Holtmann N, Edimiris P, Andree M, Doehmen C, Baston-Buest D, et al. (2020) Assessment of SARS-CoV-2 in human semen-a cohort study. Fertil Steril. 114(2):233-238.

23. Semet M, Paci M, Saïas-Magnan J, Metzler-Guillemain C, Boissier R, et al. (2017) The impact of drugs on male fertility: a review. Andrology. 5(4):640-663.

24. Carlsen E, Andersson AM, Petersen JH, Skakkebaek NE. (2003) History of febrile illness and variation in semen quality. Hum Reprod. 18(10):2089-92.

25. Li D, Jin M, Bao P, Zhao W, Zhang S. (2020) Clinical Characteristics and Results of Semen Tests Among Men With Coronavirus Disease 2019. JAMA Netw Open. 3(5):e208292.

26. Tur-Kaspa I, Tur-Kaspa T, Hildebrand G, Cohen D. (2021) COVID-19 May Affect Male Fertility but is Not Sexually Transmitted: A Systematic Review. F S Rev., Epub ahead of print.

27. Ma X, Guan C, Chen R, Wang Y, Feng S, et al. (2021) Pathological and molecular examinations of postmortem testis biopsies reveal SARS-CoV-2 infection in the testis and spermatogenesis damage in COVID-19 patients. Cell Mol Immunol. 18(2):487-489.

28. Li H, Xiao X, Zhang J, Zafar MI, Wu C, et al. (2020) Impaired spermatogenesis in COVID-19 patients. EClinicalMedicine. 28:100604.

29. Achua JK, Chu KY, Ibrahim E, Khodamoradi K, Delma KS, et al. (2021) Histopathology and Ultrastructural Findings of Fatal COVID-19 Infections on Testis. World $\mathbf{J}$ Mens Health. 202139(1):65-74.

30. Yang M, Chen S, Huang B, Zhong JM, Su H, et al, (2020) Pathological Findings in the Testes of COVID-19 Patients: Clinical Implications. Eur Urol Focus. 6(5):1124-1129.

31. Nie X, Qian L, Sun R, Huang B, Dong X, Xiao Q, et al. (2021) Multi-organ proteomic landscape of COVID-19 autopsies. Cell. 184(3):775-791.e14.

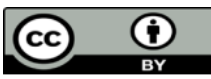

This work is licensed under Creative Commons Attribution 4.0 License

To Submit Your Article Click Here: Submit Manuscript

DOI: $10.31579 / 2640-1045 / 066$
Ready to submit your research? Choose Auctores and benefit from:

* fast, convenient online submission

* rigorous peer review by experienced research in your field

* rapid publication on acceptance

* authors retain copyrights

* unique DOI for all articles

* immediate, unrestricted online access

At Auctores, research is always in progress.

Learn more www.auctoresonline.org/journals/endocrinology-anddisorders 